\title{
Growth, production and water and nitrogen use efficiency of maize under water depths and nitrogen fertilization
}

\author{
David H. Campelo ${ }^{1}$, Adunias dos S. Teixeira ${ }^{1}$, Luis C. J. Moreira ${ }^{2}$ \& Claudivan F. de Lacerda ${ }^{1}$ \\ ${ }^{1}$ Universidade Federal do Ceará/Departamento de Engenharia Agrícola. Fortaleza, CE, Brasil. E-mail: davidcamppelo@gmail.com (Corresponding author) \\ - ORCID: 0000-0001-6990-3724; adunias@pq.cnpq.br - ORCID: 0000-0002-1480-0944; claudivan_@hotmail.com - ORCID: 0000-0002-5324-8195 \\ ${ }^{2}$ Instituto Federal de Educação, Ciência e Tecnologia do Ceará. Limoeiro do Norte, CE, Brasil. E-mail: cleniojario@gmail.com - ORCID: 0000-0001- \\ 9918-9744
}

\begin{abstract}
The objective of this study was to evaluate the growth, the production components and the water (WUE) and nitrogen use efficiency (NUE) in maize (Zea mays L.), as function of water depths and nitrogen doses. The experimental design was randomized blocks in a split-plot scheme with four repetitions. The irrigation treatments applied in the plots were composed of four water depths: 80, 90, 100 and $110 \%$ of the water requirement, based on the soil field capacity, while the $\mathrm{N}$ doses, distributed in the subplots, were $0,60,120$ and $180 \mathrm{~kg} \mathrm{ha}^{-1}$. Increases in water depths and in $\mathrm{N}$ doses promote linear increases in plant height and leaf area index. For cycle I (2015) the maximum yield (16,778.3 $\left.\mathrm{kg} \mathrm{ha}^{-1}\right)$ was reached with the irrigation depth of $538.1 \mathrm{~mm}$ and nitrogen dose of $180 \mathrm{~kg} \mathrm{ha}^{-1}$; and for cycle II (2016), the maximum yield was reached with the irrigation depth corresponding to $505 \mathrm{~mm}$ and $\mathrm{N}$ dose of $180 \mathrm{~kg} \mathrm{ha}^{-1}$, yielding $17,819.5 \mathrm{~kg} \mathrm{ha}^{-1}$. The highest values of WUE (4.1 and $3.8 \mathrm{~kg} \mathrm{~m}^{-3}$ ) were estimated in cycle I (2015) for $432.7 \mathrm{~mm}$ and in cycle II (2016) for $359.6 \mathrm{~mm}$, respectively; while the highest values of NUE (67.5 and $\left.65.3 \mathrm{~kg} \mathrm{~kg}^{-1}\right)$ were estimated in cycle I (2015), for the water depth of $555.7 \mathrm{~mm}$ and nitrogen dose of $113.3 \mathrm{~kg} \mathrm{ha}^{-1}$, and in cycle II (2016), for the water depth of $506 \mathrm{~mm}$ and nitrogen dose of $107.7 \mathrm{~kg} \mathrm{ha}^{-1}$.
\end{abstract}

Key words: Zea mays L., irrigation management, mineral fertilization

\section{Crescimento, produção e eficiências do uso de água e nitrogênio do milho sob lâminas e adubações nitrogenadas}

RESUMO: Objetivou-se neste estudo avaliar o crescimento, os componentes de produção e as eficiências do uso da água (EUA) e do nitrogênio (EUN) na cultura do milho (Zea mays L.), em função de lâminas de irrigação e doses de nitrogênio. O delineamento experimental adotado foi o de blocos casualizados em esquema de parcelas subdivididas com quatro repetições. Os tratamentos de irrigação aplicados nas parcelas foram compostos de quatro lâminas de água: 80, 90, 100 e 110\% do requerimento hídrico, baseadas na capacidade de campo do solo, e as doses de N, distribuídas nas subparcelas foram: 0, 60, 120 e $180 \mathrm{~kg} \mathrm{ha}^{-1}$. Aumentos nas lâminas de irrigação e nas doses de $\mathrm{N}$ promovem aumentos lineares na altura das plantas e no índice de área foliar. Para o ciclo I (2015) a produtividade máxima (16.778,3 $\left.\mathrm{kg} \mathrm{ha}^{-1}\right)$ foi alcançada com a lâmina de irrigação de 538,1 mm e dose de nitrogênio de $180 \mathrm{~kg} \mathrm{ha}^{-1}$; e para o ciclo II (2016), a máxima produtividade foi alcançada com a lâmina de irrigação correspondente a $505 \mathrm{~mm}$ e a dose de $\mathrm{N}$ de $180 \mathrm{~kg} \mathrm{ha}^{-1}$, obtendo-se $17.819,5 \mathrm{~kg} \mathrm{ha}^{-1}$. Os maiores valores de EUA (4,1 e 3,8 $\mathrm{kg} \mathrm{m}^{-3}$ ) foram estimados no ciclo I (2015) para $432,7 \mathrm{~mm}$ e no ciclo II (2016) para $359,6 \mathrm{~mm}$, respectivamente; enquanto os maiores valores de EUN (67,5 e $\left.65,3 \mathrm{~kg} \mathrm{~kg}^{-1}\right)$ foram estimados no ciclo I (2015) para a lâmina de irrigação de 555,7 mm e dose de nitrogênio de $113,3 \mathrm{~kg} \mathrm{ha}^{-1}$, e no ciclo II (2016) para a lâmina de irrigação de $506 \mathrm{~mm}$ e dose de nitrogênio de $107,7 \mathrm{~kg} \mathrm{ha}^{-1}$.

Palavras-chave: Zea mays L., manejo da irrigação, adubação mineral 


\section{INTRODUCTION}

Maize (Zea mays L.) is one of the most exploited crops in the world, assuming an important role in the international scenario of food production, being also one of the main irrigated crops and responsible for the use of agricultural inputs (FAO, 2017). Currently, much of the research focus on the efficiency in the use of resources aiming to increase yield and the same time reduce the environmental impacts generated by the agricultural activity (Mueller et al., 2012).

In most agricultural systems, crop yield is mainly limited by factors such as low nutrient and water availability, because they compromise physiological processes related to plant growth (Gonzalez-Dugo et al., 2010 ). The main nutrient required by the maize crop is nitrogen $(\mathrm{N})$, because it is highly related to the reduction in plant production and to yield components (Teixeira et al., 2014; Wang et al., 2017). The large demand for inorganic $\mathrm{N}$-based fertilizers often results in high application rates in the production process, thus requiring a rational management that considers the economic and environmental impacts of these practices (Djaman et al., 2013; Jia et al., 2014). In addition, the success of agricultural production is associated with the management of water resources. The limitation of the amount of water for irrigation has required the maximum of techniques that result in the efficiency of use of this resource and lower impact on yield (Paolo \& Rinaldi, 2008; Kresovic et al., 2016). In view of the above, improvement in water and $\mathrm{N}$ use efficiency is a desirable characteristic and plays a vital role in the increase and optimization of agricultural production (Quemada \& Gabriel, 2016 ).

In this context, the present study aims to evaluate the growth, the production components and the water (WUE) and nitrogen use efficiency (NUE) in maize (Zea mays L.), as a function of water depth and nitrogen dose under field conditions.

\section{Material ANd Methods}

The study was conducted in an experimental area at the Laboratory of Hydraulics and Irrigation of the Departamento de Engenharia Agrícola of the Universidade Federal do Ceará, Pici Campus, located in the municipality of Fortaleza, CE, Brazil (3 45' S; 38 33' W; altitude of 19 m). According to Köppen's classification, the experimental area is located in a region of Aw' climate. The soil of the area is classified as an Ultisol.

Maize plants AG 1051 hybrid, were cultivated in the period from September to December 2015 (cycle I) and from November 2016 to January 2017 (cycle II).

The experimental design was randomized blocks, in a split-plot scheme with four repetitions, with the main plot composed of four irrigation depths $(\mathrm{L} 110=110 \%, \mathrm{~L} 100=$
$100 \%, \mathrm{~L} 90=90 \%$ and $\mathrm{L} 80=80 \%$ of the water requirement), based on the moisture content at field capacity (FC) and the subplot with four doses of nitrogen fertilization $\left(\mathrm{N} 0=0 \mathrm{~kg} \mathrm{ha}^{-1}\right.$, $\mathrm{N} 60=60 \mathrm{~kg} \mathrm{ha}^{-1}, \mathrm{~N} 120=120 \mathrm{~kg} \mathrm{ha}^{-1}$ and N180 $=180 \mathrm{~kg} \mathrm{ha}^{-1}$ of $\mathrm{N})$ considering the dose of $120 \mathrm{~kg} \mathrm{ha}^{-1}$ as the amount required according to soil analysis. The detailed description of the water depth applied is presented in Table 1.

The total water depth was considered as the sum of the irrigation depths with rainfall occurring during the experiment. The rains that occurred during the experimental phase were 10 and $98.80 \mathrm{~mm}$, in the 2015 and 2016 cycles, respectively.

The source of $\mathrm{N}$ used was urea, $\mathrm{CO}\left(\mathrm{NH}_{2}\right)_{2}$. The fertilization was complemented in all treatments with $60 \mathrm{~kg} \mathrm{ha}^{-1}$ of $\mathrm{P}_{2} \mathrm{O}_{5}$, $70 \mathrm{~kg} \mathrm{ha}^{-1}$ of $\mathrm{K}_{2} \mathrm{O}$ and $30 \mathrm{~kg} \mathrm{ha}^{-1}$ of FTE BR 12. Phosphorus and micronutrients were entirely applied at planting, while $\mathrm{K}$ was applied $60 \%$ at planting and $40 \%$ as topdressing, respectively, at 14 and 35 days after planting (DAP). Nitrogen was applied through drip fertigation and splitted equally, with applications every 7 days from planting and continuing during the experiment.

Irrigation was performed with a drip system and managed by means of capacitive moisture sensors. Irrigation time was calculated daily for each water depth treatment, according to the water depth required, using Eq. 1.

$$
\mathrm{Ti}=\frac{\left(\theta_{\mathrm{t}}-\theta_{\mathrm{a}}\right) z \mathrm{Ea}}{\mathrm{I}_{\mathrm{a}} \mathrm{K}_{\mathrm{r}}}
$$

where:

$\mathrm{Ti} \quad$ - irrigation time, $\mathrm{h}$;

$\Theta_{t} \quad$ - target soil moisture, $\mathrm{cm}^{3} \mathrm{~cm}^{-3}$;

$\Theta_{\mathrm{a}} \quad$ - actual soil moisture, $\mathrm{cm}^{3} \mathrm{~cm}^{-3}$;

$\mathrm{z}$ - root system depth, cm;

Ea - water application efficiency;

$\mathrm{I}_{\mathrm{a}}$ - application rate, $\mathrm{mm} \mathrm{h}^{-1}$; and,

$\mathrm{K}_{\mathrm{r}}^{\mathrm{a}}$ - coefficient of reduction.

The following variables were evaluated: leaf area index (LAI), plant height $(\mathrm{PH})$, yield of ears without straw (YE), water (WUE) and nitrogen use efficiency (NUE). LAI was determined by collecting leaves of three plants per experimental unit, using the device LI - 3100 (Li - Cor. Inc. Lincoln, Nebraska, USA). PH was measured using a graduated ruler. For YE evaluation, 20 plants were harvested per experimental unit. The total weight of ears without straw was determined and expressed as $\mathrm{kg} \mathrm{ha}^{-1}$. All variables were evaluated at 75 days after planting.

Water use efficiency (WUE) was calculated using the data of crop yield and total water volume applied during the cycle, according to Eq. 2.

Table 1. Description of water depths applied

\begin{tabular}{|c|c|c|c|c|}
\hline \multirow[t]{2}{*}{ Treatment } & \multirow{2}{*}{$\begin{array}{l}\text { Field capacity } \\
\text { percentage (\%) }\end{array}$} & \multirow{2}{*}{$\begin{array}{l}\text { Volumetric soil moisture used } \\
\text { as setpoint }\left(\mathrm{cm}^{3} \mathrm{~cm}^{-3}\right)\end{array}$} & \multicolumn{2}{|c|}{$\begin{array}{l}\text { Total water depth applied + rainfall } \\
(\mathrm{mm})\end{array}$} \\
\hline & & & Cycle I (2015) & Cycle II (2016) \\
\hline L110 & 110 & 24.41 & 555.7 & 506.0 \\
\hline L100 & 100 & 21.90 & 485.3 & 433.5 \\
\hline L90 & 90 & 19.71 & 395.8 & 392.8 \\
\hline L80 & 80 & 17.52 & 359.6 & 369.3 \\
\hline
\end{tabular}




$$
\mathrm{WUE}=\frac{\mathrm{Y}}{\mathrm{I}}
$$

where:

WUE - water use efficiency, $\mathrm{kg} \mathrm{m}^{-3}$;

Y - Yield, $\mathrm{kg} \mathrm{ha}^{-1}$; and,

I - Water depth applied, $\mathrm{m}^{3} \mathrm{ha}^{-1}$.

The agronomic nitrogen use efficiency (NUE) was obtained using Eq. 3.

$$
\mathrm{NUE}=\frac{\mathrm{Y}_{\mathrm{N}}-\mathrm{Y}_{0}}{\mathrm{~N}_{\mathrm{T}}}
$$

where:

NUE - nitrogen use efficiency, $\mathrm{kg} \mathrm{kg}^{-1}$;

$\mathrm{Y}_{\mathrm{N}} \quad$ - yield of ears with nitrogen fertilizer, $\mathrm{kg} \mathrm{ha}^{-1}$;

$\mathrm{Y}_{0} \quad$ - yield of ears without nitrogen fertilizer, $\mathrm{kg} \mathrm{ha}^{-1}$; and,

$\mathrm{N}_{\mathrm{T}}$ - doses of $\mathrm{N}$ applied, $\mathrm{kg} \mathrm{ha}^{-1}$.

The data were submitted to analysis of variance and regression analysis. The equations that fitted best to the data were chosen based on the t-test, significance of regression coefficients $(\mathrm{p} \leq 0.05)$ and the adjusted coefficient of determination $\left(R^{2}\right.$ adj).

\section{Results AND Discussion}

Plant height $(\mathrm{PH})$, leaf area index (LAI), yield of ears (YE) and nitrogen use efficiency (NUE) were significantly influenced by the single factors (water depth and nitrogen fertilization), as well as by their interaction. For water use efficiency (WUE), there were only single effects of the factors (Table 2 ).

Table 2. Summary of analysis of variance for plant height $(\mathrm{PH})$, leaf area index (LAI), yield of ears (YE), water (WUE) and nitrogen use efficiency (NUE) for the cycles I (2015) and

\begin{tabular}{|c|c|c|c|c|c|c|}
\hline \multirow{2}{*}{ SV } & \multirow{2}{*}{ DF } & \multicolumn{5}{|c|}{ F value } \\
\hline & & PH & LAI & YE & WUE & NUE \\
\hline \multicolumn{7}{|c|}{ Cycle I (2015) } \\
\hline Block & 3 & $4.65^{\star}$ & 2.97 ns & $3.11^{\mathrm{ns}}$ & $2.51^{\text {ns }}$ & $2.15^{\mathrm{ns}}$ \\
\hline Water depth - a & 3 & $36.66^{\star *}$ & $11.01^{* *}$ & $61.47^{* *}$ & $4.20^{\star}$ & $7.69 * *$ \\
\hline Residual - a & 9 & & & & & \\
\hline Fertilization - b & 3 & $31.26^{\star \star}$ & $12.21^{* *}$ & $204.64 * *$ & $201.05^{\star *}$ & $123.4^{* *}$ \\
\hline$a \times b$ & 9 & $2.19^{\star}$ & $0.26^{\star}$ & $3.49 * \star$ & 1.89 ns & 2.30 * \\
\hline Residual - b & 36 & & & & & \\
\hline Total & 63 & & & & & \\
\hline CV a (\%) & & 8.31 & 19.61 & 8.85 & 10.47 & 26.70 \\
\hline CV b (\%) & & 7.03 & 15.79 & 7.40 & 7.46 & 24.67 \\
\hline \multicolumn{7}{|c|}{ Cycle II (2016) } \\
\hline Block & 3 & $2.38^{\text {ns }}$ & $6.17^{\mathrm{ns}}$ & $2.49^{\text {ns }}$ & $2.35^{\text {ns }}$ & 5.05 * \\
\hline Water depth - a & 3 & $50.34^{* *}$ & $46.59 * *$ & $3.16^{\text {ns }}$ & $10.93^{* *}$ & 26.24 ** \\
\hline Residual - a & 9 & & & & & \\
\hline Fertilization - b & 3 & $87.45^{\star \star}$ & $284.40^{\star \star *}$ & $57.45^{\star \star}$ & $48.013^{\star \star}$ & $58.90 \star \star$ \\
\hline$a \times b$ & 9 & $3.01^{\star \star}$ & $4.91^{\star \star}$ & $2.90^{\star}$ & $1.53^{\mathrm{ns}}$ & $3.20^{\star \star}$ \\
\hline Residual - b & 36 & & & & & \\
\hline Total & 63 & & & & & \\
\hline CV a (\%) & & 1.93 & 4.86 & 10.31 & 11.10 & 29.61 \\
\hline CV b (\%) & & 2.21 & 4.51 & 7.38 & 8.29 & 37.63 \\
\hline
\end{tabular}
II (2016)

SV - Source of variation; DF - Degrees of freedom; $\mathrm{a}$ - Water depth; b - Fertilization CV - Coefficient of variation; ${ }^{* *},{ }^{*},{ }^{\text {ns }}$ - Significant by F test at $\mathrm{p} \leq 0.01, \mathrm{p} \leq 0.05$ and not significant, respectively
From the quantitative analysis of the response function to the interaction between the factors irrigation depth and $\mathrm{N}$ doses for the variables plant height $(\mathrm{PH})$ and leaf area index (LAI), it was possible to obtain the functions represented by the regression $(\mathrm{p} \leq 0.01)$ shown in Figure 1 .

A.

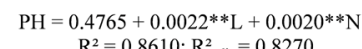
$\mathrm{R}^{2}=0.8610 ; \mathrm{R}_{\text {adj. }}^{2}=0.8270$

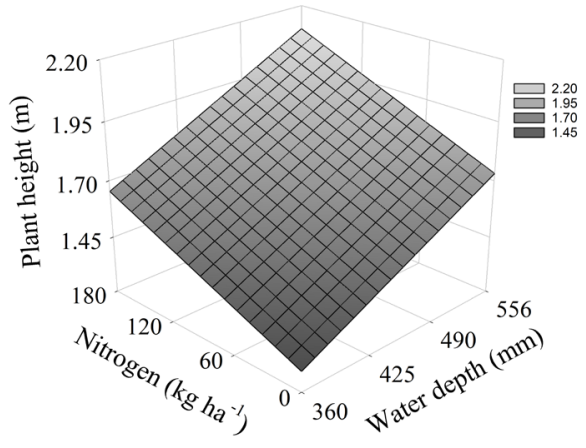

B. $\begin{aligned} \mathrm{PH}= & 1.3284+0.0009^{* * *} \mathrm{~L}+0.0011^{* *} \mathrm{~N} \\ & \mathrm{R}^{2}=0.8110 ; \mathrm{R}^{2}\end{aligned}$

C.
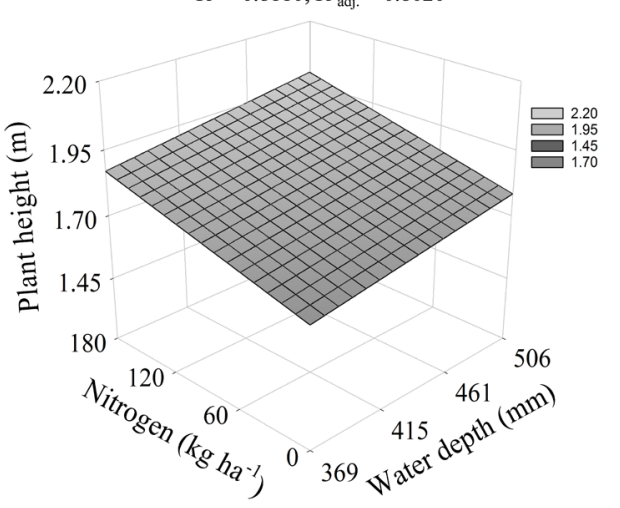

$$
\text { LAI }=0.2337+0.0038 * * \mathrm{~L}+0.0036 * * \mathrm{~N}
$$
$\mathrm{R}^{2}=0.8730 ; \mathrm{R}_{\text {adj. }}^{2}=0.8410$

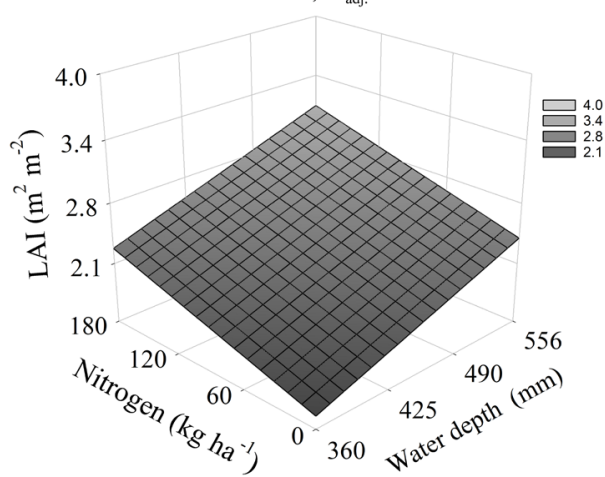

D. $\mathrm{LAI}=0.5653+0.0037 * * \mathrm{~L}+0.0068 * * \mathrm{~N}$ $\mathrm{R}^{2}=0.9410 ; \mathrm{R}_{\text {adj. }}^{2}=0.9260$

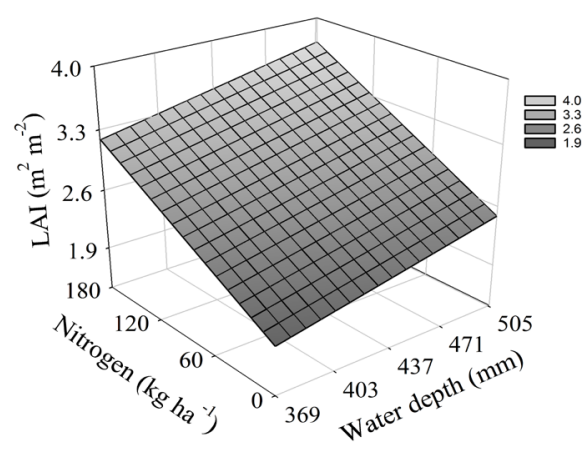

**, * - Significant at $\mathrm{p} \leq 0.01$ and $\mathrm{p} \leq 0.05$ by $\mathrm{F}$ test, respectively

Figure 1. Plant height $(\mathrm{PH})$ and leaf area index (LAI) in maize plants as a function of nitrogen doses and water depths, in cycle I - 2015 (A and C) and cycle II - 2016 (B and D) 
The variables PH and LAI increased linearly as a function of the increasing $\mathrm{N}$ doses and irrigation depths with adjusted coefficients of determination varying between 0.802 and 0.926 .

For $\mathrm{PH}$ considering the two cycles, the highest values of plant height $(2.06 \mathrm{~m}$ for cycle I and $2.03 \mathrm{~m}$ for cycle II) were obtained with the combination of water depth of $555.7 \mathrm{~mm}$ and $\mathrm{N}$ dose of $180 \mathrm{~kg} \mathrm{ha}^{-1}$, and $506 \mathrm{~mm}$ and $180 \mathrm{~kg} \mathrm{ha}^{-1}$, respectively (Figures 1A and B). For cycle I (2015), the maximum LAI value of $2.99 \mathrm{~m}^{2} \mathrm{~m}^{-2}$ occurred for $555.7 \mathrm{~mm}$ and $180 \mathrm{~kg} \mathrm{ha}^{-1}$, while for cycle II (2016) the maximum LAI value of $3.70 \mathrm{~m}^{2} \mathrm{~m}^{-2}$ was obtained using the $506 \mathrm{~mm}$ water depth and $\mathrm{N}$ dose of $180 \mathrm{~kg} \mathrm{ha}^{-1}$ (Figures $1 \mathrm{C}$ and D).

The availability of $\mathrm{N}$ and water can affect leaf expansion simultaneously. According to Taiz \& Zeiger (2013), water and nutritional deficits are responsible for mechanisms of cell dehydration and vegetative growth, respectively. In the maize crop, these two factors strongly condition the variations in plant height and leaf area (Çakir, 2004; França et al., 2011).

The reduction of $\mathrm{PH}$ as a function of the water depths and $\mathrm{N}$ doses was evidenced, with higher values in the cycle $\mathrm{I}$, on average, and reductions of 22.10 and $25.4 \%$ in the treatments (N0) and (L80) compared to the ideal supply (N100) and (L100), respectively.

For LAI, the highest reductions as a function of $\mathrm{N}$ dose were observed in the cycle II, with a $38.8 \%$ decrease in the N0 treatment compared to the N100. For the effect of irrigation depths, the reduction was $20.7 \%$ between L 80 and L100. These results are in agreement with Teixeira et al. (2014), who found effect of water and nutritional stress on the reduction of LAI in irrigated maize, attributing these results especially to variations in the capacity to allocate resources, mainly in radiation and water use efficiency. According to Wang et al. (2017), the increment in soil water availability increases $\mathrm{N}$ absorption, contributing to the linear increase of biomass in maize plants.

Regarding the yield of ears without straw (YE), the regression equations and the response surface functions indicate a quadratic polynomial effect $(\mathrm{p} \leq 0.01)$ (Figure 2$)$.

The maximum yield estimated for cycle I $\left(16,778.3 \mathrm{~kg} \mathrm{ha}^{-1}\right)$ was obtained with the combination of water depth of $538.12 \mathrm{~mm}$ and $\mathrm{N}$ dose of $180 \mathrm{~kg} \mathrm{ha}^{-1}$ (Figure 2A). In cycle II, better yields were observed, with the highest yield of $17,819.5 \mathrm{~kg} \mathrm{ha}^{-1}$ under irrigation depth of $506 \mathrm{~mm}$ and $\mathrm{N}$ dose of $180 \mathrm{~kg} \mathrm{ha}^{-1}$ (Figure 2B).

These results are in agreement with Gholamhoseini et al. (2013), who found a trend of reduction in maize yield under high $\mathrm{N}$ doses in irrigation systems with high frequency, and with Irmak et al. (2016), who found quadratic trend in grain yield as a function of varying levels of irrigation supply.

The results suggest that water availability amplifies the gain yield through a better use of N. According to Paolo \& Rinaldi (2008), the influence of $\mathrm{N}$ availability on maize yield tends to be lower under water restriction.

In this study, the water limitations were moderate with a maximum reduction of $20 \%$ of field capacity, but were sufficient to reduce yield, even at the recommended doses. Low yield under low levels of water in soil is linked, among other factors, to the drop in production and translocation of photoassimilates and, consequently, absorption by grains (Aydinsakir et al., 2013).
A. $\quad \mathrm{YE}=-29742.533+146.654 * \mathrm{~L}-0.1362 * \mathrm{~L}^{2}+58.465 * \mathrm{~N}-0.1068 * \mathrm{~N}^{2}$ $\mathrm{R}^{2}=0.9480 ; \mathrm{R}_{\text {adj. }}^{2}=0.9220$

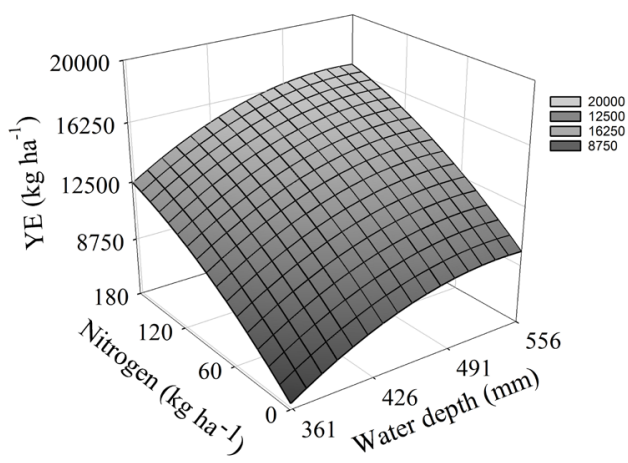

B. $Y E=8598.733+4.703 * \mathrm{~L}+0.0071 * \mathrm{~L}^{2}+37.826 * \mathrm{~N}-0.0558 * \mathrm{~N}^{2}$ $\mathrm{R}^{2}=0.8770 ; \mathrm{R}_{\text {adj. }}^{2}=0.8060$

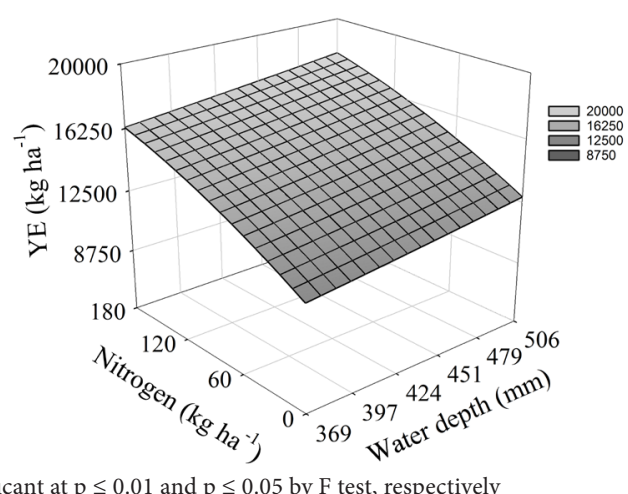

**, * - Significant at $\mathrm{p} \leq 0.01$ and $\mathrm{p} \leq 0.05$ by $\mathrm{F}$ test, respectively

Figure 2. Yield of ears without straw (YE) in maize plants as a function of nitrogen doses and water depths, in cycle I - 2015 (A) and cycle II - 2016 (B)

The results also indicate that, at adequate levels of soil water, maize plants improved the simultaneous absorption of water and $\mathrm{N}$, increasing the efficiency in the use of these resources. Gholamhoseini et al. (2013) report higher $\mathrm{N}$ response in maize yield under favorable soil water conditions, with a $63 \%$ increase in comparison to the reduced water regime under semiarid conditions.

The response surfaces of nitrogen use efficiency (NUE) for the two cultivation cycles are shown in Figure 3.

The best fit was obtained by the quadratic polynomial model $(\mathrm{p} \leq 0.01)$. The NUE values varied between the production cycles. In cycle I, the best $\mathrm{N}$ use efficiency $\left(67.5 \mathrm{~kg} \mathrm{~kg}^{-1}\right)$ was obtained with water depth of $555.7 \mathrm{~mm}$ and $\mathrm{N}$ dose of $113.3 \mathrm{~kg} \mathrm{ha}^{-1}$. In cycle II, the maximum point $\left(65.3 \mathrm{~kg} \mathrm{~kg}^{-1}\right)$ was reached with a combination of water depth of $506 \mathrm{~mm}$ and $\mathrm{N}$ dose of $107.5 \mathrm{~kg} \mathrm{ha}^{-1}$.

In relation to NUE, it was observed that the adequate water supply improved the efficiency in $\mathrm{N}$ use by the plant. These results indicate, mainly, that excess of $\mathrm{N}$ application tends to reduce the efficiency of use by plants. This is directly related to the losses by application and by limitation in the absorption of this nutrient by plants.

According to Valero et al. (2005), NUE tends to decrease with the increase in fertilizer rates. Fernandes et al. (2005), in a study with six maize cultivars with different $\mathrm{N}$ doses, obtained higher values of NUE under $\mathrm{N}$ dose of $30 \mathrm{~kg} \mathrm{ha}^{-1}$, decreasing when $\mathrm{N}$ doses increased to 90 and $180 \mathrm{~kg} \mathrm{ha}^{-1}$.

In the present study, differently, the highest value was found at the recommended dose $\left(\mathrm{N} 120=120 \mathrm{~kg} \mathrm{ha}^{-1}\right)$, compared to 
A. $\quad \mathrm{NUE}=-31.3139+0.0721 * \mathrm{~L}+1.0270 * * \mathrm{~N}-0.0045^{* *} \mathrm{~N}^{2}$ $\mathrm{R}^{2}=0.9210 ; \mathrm{R}_{\mathrm{adj} .}^{2}=0.8930$

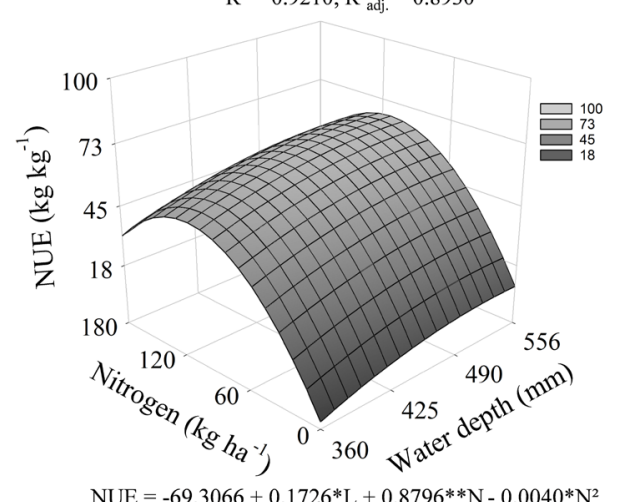

B.

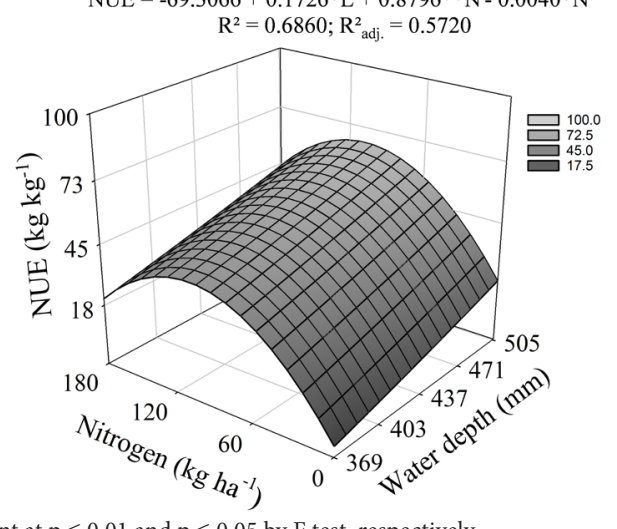

**, * - Significant at $\mathrm{p} \leq 0.01$ and $\mathrm{p} \leq 0.05$ by $\mathrm{F}$ test, respectively

Figure 3. Nitrogen use efficiency (NUE) in maize plants as a function of nitrogen doses and water depths in cycle I - 2015 (a) and cycle II - 2016 (B)

the deficit dose $\left(\mathrm{N} 60=60 \mathrm{~kg} \mathrm{ha}^{-1}\right)$. These results may be related to the reduction of potential losses due to the greater splitting of the applications and, consequently, better absorption capacity, besides the high yields achieved with the doses N120 $=120 \mathrm{~kg} \mathrm{ha}^{-1}$ and $\mathrm{N} 180=180 \mathrm{~kg} \mathrm{ha}^{-1}$, compared to N60.

According to Binder et al. (2000), the splitting promotes greater use of $\mathrm{N}$ through the synchronization between the applications and periods of high demand, with effects on the production. Thus, the quadratic trends of NUE as a function of the irrigation depths may differ from those of other studies found in the literature, depending on the mode of application of $\mathrm{N}$ and the irrigation method adopted.

Differences in NUE as a function of doses of $\mathrm{N}$ and water depths are reported in the literature. For example, Pandey et al. (2000), in a study with the maize crop, found increasing linear trend of NUE as a function of the irrigation depth. In this case, the higher water availability in the soil favored better $\mathrm{N}$ use by plants, through the increase in $\mathrm{N}$ absorption under conditions of total water supply, compared to the $57 \%$ reduction in the irrigation. However, Chilundo et al. (2016) found higher NUE values under conditions of lower water availability in treatments with $25 \%$ reduction in drip system; in this case, $\mathrm{N}$ losses were associated with the highest irrigation depths, which were larger than the storage capacity.

According to Djaman et al. (2013), excess of irrigation favors the residual loss of $\mathrm{NO}_{3}^{-}$, through either leaching or denitrification, due to its high mobility in soil under high moisture conditions, causing a reduction in the efficiency of $\mathrm{N}$ use for production.
It should be pointed out that, in the present experiment, the reductions ranged by a maximum of $20 \%$ of the water requirement, based on the monitoring via soil, rather than the calculation of water requirement considering the climate.

According to Zotarelli et al. (2011), the use of soil moisture sensors to meet the actual water requirement of plants tends to improve NUE, due to the greater control in the amount of water applied and the consequent maintenance of $\mathrm{N}$ close to their root zone, resulting in lower losses through $\mathrm{NO}_{3}$ leaching. Moreover, the supply closer to the actual requirement of the crop combined to adequate fertilization through fertigation, for instance, tends to increase NUE in crops (Quemada \& Gabriel, 2016).

The result of the regression analysis for water use efficiency (WUE) considering the single factors is presented in Figure 4. In regard to WUE as a function of the water depths for cycle I, there was a quadratic response ( $\mathrm{p} \leq 0.05)$, with maximum values estimated for $432.7 \mathrm{~mm}$ (Figure $4 \mathrm{~A}$ ), whereas for cycle II, a linear model was adjusted ( $\mathrm{p} \leq 0.05)$, with reduction in WUE as a function of irrigation depths (Figure 4C).

Regarding the WUE as a function of $\mathrm{N}$ doses, a linear effect $(p \leq 0.05)$ was observed for both cycles, with the increment of WUE as a function of the increase in $\mathrm{N}$ doses (Figures $4 \mathrm{~B}$ and D).

The reduction in WUE as a function of the increase in water availability is in agreement with studies found in the literature, such as Aydinsakir et al. (2013), who found better WUE in maize in treatments with $50 \%$ of crop requirement, compared to the irrigation levels of 75 and $100 \%$. In a similar study, Irmak et al. (2016) reported reduction in WUE as a function of the decrease of irrigation depth in maize, and reported that the application beyond its water requirement may have contributed more to biomass production instead of increasing grain yield, potentially decreasing the WUE.

The reduction in WUE under higher water depths demonstrates the importance of maintaining adequate water depth for the crop by improving the absorption of available water in soil. Zotarelli et al. (2010) compared combinations of three doses of $\mathrm{N}$ and three treatments of drip irrigation in bell pepper (Capsicum annuum L.) and verified $62 \%$ reduction in the optimal amount of water applied in treatment based on real-time maintenance of soil moisture, compared to the conventional method via climate, without compromising the marketable yield.

The linear increase in WUE with the application of increasing $\mathrm{N}$ doses $(\mathrm{p} \leq 0.05)$ (Figures $4 \mathrm{~B}$ and $\mathrm{D})$ suggests that well-nourished plants improve their capacity for water absorption and use in the production of photoassimilates.

Similar results were obtained by Teixeira et al. (2014), who demonstrated that water use efficiency increases by around $20 \%$ in adequately fertilized maize plants, regardless of the water condition imposed. In a study on the effect of the interaction between $\mathrm{N}$ fertilization and irrigation on maize yield, Gheysari et al. (2015) observed reduction in NUE with the decrease in water depths, indicating that the greater supply of $\mathrm{N}$ increases the tolerance in terms of yield when the crop is subjected to water stress. 

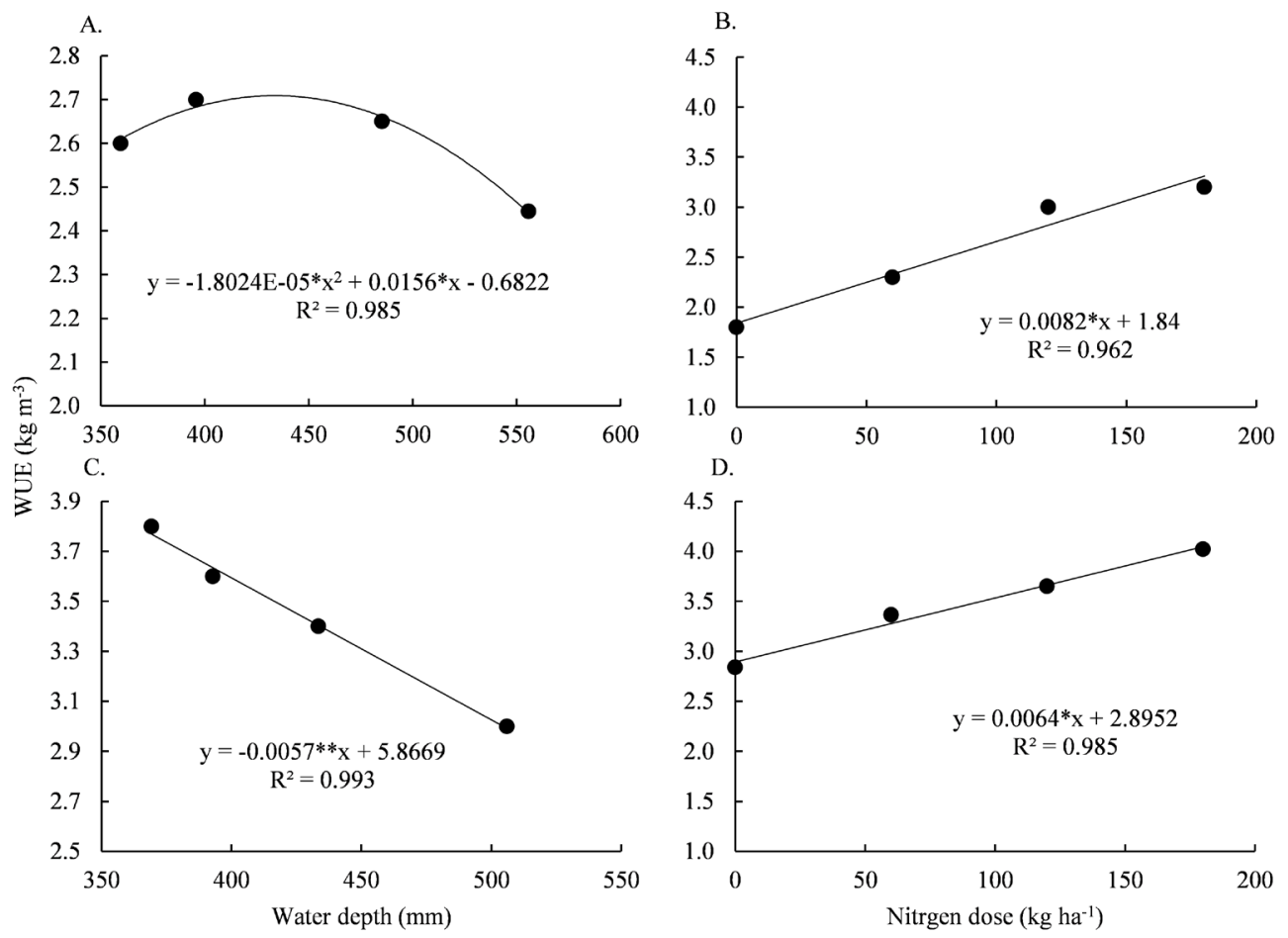

**, * - Significant at $\mathrm{p} \leq 0.01$ and $\mathrm{p} \leq 0.05$ by $\mathrm{F}$ test, respectively

Figure 4. Water use efficiency (WUE) as a function of water depths and nitrogen doses for cycle I - 2015 (A and B) and cycle II - 2016 (C and D)

Both WUE and NUE decrease beyond field capacity and recommended dose, respectively, suggesting that a balance between the supplies of $\mathrm{N}$ and water should be considered. In this study, the highest yield was observed in the treatment L100 $(506 \mathrm{~mm})$ and N180 (180 $\left.\mathrm{kg} \mathrm{ha}^{-1}\right)$ in cycle II $\left(17819.5 \mathrm{~kg} \mathrm{ha}^{-1}\right)$, demonstrating that, in terms of yield, the adequate water content was determinant, but the dose higher than the recommended (N180) was the one which led to the highest production.

Increase of yield under higher availability of $\mathrm{N}$ and water, even beyond the recommended dose in maize crop, is documented by Jia et al. (2014) but, as previously mentioned, excess of irrigation depth and $\mathrm{N}$ application greater than the absorption capacity by the crop intensifies the residual effect of nitrate in the soil. Thus, fertilizer application rates combined with the maintenance of water in soil at adequate levels are the key to increasing yield and reducing environmental impacts.

\section{Conclusions}

1. Increases in water depths and in $\mathrm{N}$ doses promote linear increases in plant height and leaf area index.

2. For cycle I (2015) the maximum yield $\left(16,778.3 \mathrm{~kg} \mathrm{ha}^{-1}\right)$ was reached with the irrigation depth of $538.1 \mathrm{~mm}$ and nitrogen dose of $180 \mathrm{~kg} \mathrm{ha}^{-1}$; and for cycle II (2016), the maximum yield was reached with the irrigation depth corresponding to 505 $\mathrm{mm}$ and $\mathrm{N}$ dose of $180 \mathrm{~kg} \mathrm{ha}^{-1}$, yielding 17,819.5 $\mathrm{kg} \mathrm{ha}^{-1}$.

3. The highest values of WUE (4.1 and $\left.3.8 \mathrm{~kg} \mathrm{~m}^{-3}\right)$ were estimated in cycle I (2015) for $432.7 \mathrm{~mm}$ and in cycle II (2016) for $359.6 \mathrm{~mm}$, respectively; while the highest values of NUE ( 67.5 and $65.3 \mathrm{~kg} \mathrm{~kg}^{-1}$ ) were estimated in cycle I (2015), for the water depth of $555.7 \mathrm{~mm}$ and nitrogen dose of $113.3 \mathrm{~kg}$ $\mathrm{ha}^{-1}$, and in cycle II (2016), for the water depth of $506 \mathrm{~mm}$ and nitrogen dose of $107.7 \mathrm{~kg} \mathrm{ha}^{-1}$.

\section{Literature Cited}

Aydinsakir, K.; Erdal, S.; Buyuktas, D.; Bastug, R.; Toker, R. The influence of regular deficit irrigation applications on water use, yield, and quality components of two corn (Zea mays L.) genotypes. Agricultural Water Management, v.128, p.65-71, 2013. https://doi.org/10.1016/j.agwat.2013.06.013

Binder, D. L.; Sander, D. H.; Walters, D. T. Maize response to time of nitrogen application as affected by level of nitrogen deficiency. Agronomy Journal, v.92, p.1228-1236, 2000. https://doi. org/10.2134/agronj2000.9261228x

Çakir, R. Effect of water stress at different development stages on vegetative and reproductive growth of corn. Field Crops Research, v.89, p.1-16, 2004. https://doi.org/10.1016/j.fcr.2004.01.005

Chilundo, M. N. G.; Joel, A.; Wesström, I.; Brito, R.; Messing, I. Effects of reduced irrigation dose and slow release fertiliser on nitrogen use efficiency and crop yield in a semi-arid loamy sand. Agricultural Water Management, v.168, p.68-77, 2016. https:// doi.org/10.1016/j.agwat.2016.02.004

Djaman, K.; Irmak, S.; Martin, D. L.; Ferguson, R. B.; Bernards, M. L. Plant nutrient uptake and soil nutrient dynamics under full and limited irrigation and rainfed maize production. Agronomy Journal, v.105, p.527-538, 2013. https://doi.org/10.2134/agronj2012.0269

FAO - Food and Agriculture Organization. Statistics division. Availalbe on: < http://faostat3.fao.org/>. Accessed on: Apr. 2017.

Fernandes, F. C. S.; Buzetti, S.; Arf, O.; Andrade, J. A. da C. Doses, eficiência e uso de nitrogênio por seis cultivares de milho. Revista Brasileira de Milho e Sorgo, v.4, p.195-204, 2005. https://doi. org/10.18512/1980-6477/rbms.v4n2p195-204

França, S.; Mielniczuk, J.; Rosa, L. M. G.; Bergamaschi, H.; Bergonci, J. I. Nitrogênio disponível ao milho: Crescimento, absorção e rendimento de grãos. Revista Brasileira de Engenharia Agrícola e Ambiental, v.15, p.1143-1151, 2011. https://doi.org/10.1590/ S1415-43662011001100006 
Gheysari, M.; Loescher, H. W.; Sadeghi, S. H.; Mirlatifi, S. M.; Zareian, M. J.; Hoogenboom, G. Water-yield relations and water use efficiency of maize under nitrogen fertigation for semiarid environments: Experiment and synthesis. Advances in Agronomy, v.130, p.175-229, 2015. https://doi.org/10.1016/ bs.agron.2014.12.001

Gholamhoseini, M.; Agha-Alikhani, M.; Sanavy, S. A. M. M.; Mirlatifi, S. M. Interactions of irrigation, weed and nitrogen on corn yield, nitrogen use efficiency and nitrate leaching. Agricultural Water Management, v.126, p.9-18, 2013. https://doi.org/10.1016/j. agwat.2013.05.002

Gonzalez-Dugo, V.; Durand, J.-L.; Gastal, F. Water deficit and nitrogen nutrition of crops: A review. Agronomy for Sustainable Development, v.30, p.529-544, 2010. https://doi.org/10.1051/agro/2009059

Irmak, S.; Djaman, K.; Rudnick, D. R. Effect of full and limited irrigation amount and frequency on subsurface drip-irrigated maize evapotranspiration, yield, water use efficiency and yield response factors. Irrigation Science, v.34, p.271-286, 2016. https:// doi.org/10.1007/s00271-016-0502-Z

Jia, X.; Shao, L.; Liu, P.; Zhao, B.; Gu, L.; Dong, S.; Bing, S. H.; Zhang, J.; Zhao, B. Effect of different nitrogen and irrigation treatments on yield and nitrate leaching of summer maize (Zea mays L.) under lysimeter conditions. Agricultural Water Management, v.137, p.92-103, 2014. https://doi.org/10.1016/j.agwat.2014.02.010

Kresović, B.; Tapanarova, A.; Tomić, Z.; Životić, L.; Vujović, D.; Sredojević, Z.; Gajić, B. Grain yield and water use efficiency of maize as influenced by different irrigation regimes through sprinkler irrigation under temperate climate. Agricultural Water Management, v.169, p.34-43, 2016. https://doi.org/10.1016/j.agwat.2016.01.023

Mueller, N. D.; Gerber, J. S.; Johnston, M.; Ray, D. K.; Ramankutty, N.; Foley, J. A. Closing yield gaps through nutrient and water management. Nature, v.490, p.254-257, 2012. https://doi. org/10.1038/nature11420
Paolo, E. di; Rinaldi, M. Yield response of corn to irrigation and nitrogen fertilization in a Mediterranean environment. Field Crops Research, v.105, p.202-210, 2008. https://doi.org/10.1016/j. fcr.2007.10.004

Pandey, R. K.; Maranville, J. W.; Chetima, M. M. Deficit irrigation and nitrogen effects on maize in a Sahelian environment: II - Shoot growth, nitrogen uptake and water extraction. Agricultural Water Management, v.46, p.15-27, 2000. https://doi.org/10.1016/S03783774(00)00074-3

Quemada, M.; Gabriel, J. L. Approaches for increasing nitrogen and water use efficiency simultaneously. Global Food Security, v.9, p.29-35, 2016. https://doi.org/10.1016/j.gfs.2016.05.004

Taiz, L.; Zeiger, E. Fisiologia vegetal. 5.ed. Porto Alegre: Artmed, 2013. 918p.

Teixeira, E. I.; George, M.; Herreman, T.; Brown, H.; Fletcher, A.; Chakwizira, E.; Maley, S.; Noble, A. The impact of water and nitrogen limitation on maize biomass and resource-use efficiencies for radiation, water and nitrogen. Field Crops Research, v.168, p.109-118, 2014. https://doi.org/10.1016/j.fcr.2014.08.002

Valero, J. A. de J.; Maturano, M.; Ramírez, A. A.; Martín-Benito, J. T.; Álvarez, J. F. O. Growth and nitrogen use efficiency of irrigated maize in a semiarid region as affected by nitrogen fertilization. Spanish Journal of Agricultural Research, v.3, p.134-144, 2005. https://doi.org/10.5424/sjar/2005031-133

Wang, Y.; Janz, B.; Engedal, T.; Neergaard, A. de. Effect of irrigation regimes and nitrogen rates on water use efficiency and nitrogen uptake in maize. Agricultural Water Management, v.179, p.271276, 2017. https://doi.org/10.1016/j.agwat.2016.06.007

Zotarelli, L.; Dukes, M. D.; Scholberg, J. M. S.; Femminella, K.; Muñoz-Carpena, R. Irrigation scheduling for green bell peppers using capacitance soil moisture sensors. Journal of Irrigation and Drainage Engineering, v.137, p.73-81, 2011. https://doi. org/10.1061/(ASCE)IR.1943-4774.0000281 